\title{
The roedderite-chayesite series from Spanish lamproites: crystal-chemical characterization
}

\author{
E. Alietti, M. F. Brigatti, S. Capedri and L. Poppi
}

Dipartimento di Scienze della Terra, Università di Modena, Via S. Eufemia, 19, I-41100 Modena, Italy

\begin{abstract}
Members of the roedderite-chayesite series in lamproites from Cancarix (SE Spain), crystallized from late magmatic residua under low $P_{\mathrm{H}_{2} \mathrm{O}}$, high temperature $\left(\sim 1100^{\circ} \mathrm{C}\right)$, oxidizing conditions. They exhibit the following main chemical variations: $0.14 \leqslant \mathrm{Na} \leqslant 0.62$ atoms per formula unit (apfu); $0.80 \leqslant$ $\mathrm{K} \leqslant 1.00 \mathrm{apfu} ; 2.97 \leqslant \mathrm{Mg} \leqslant 4.33$ apfu; $0.00 \leqslant \mathrm{Fe}^{2+} \leqslant 1.19$ apfu; $0.42 \leqslant \mathrm{Fe}^{3+} \leqslant 0.87$ apfu; they are hexagonal $(10.120 \leqslant a \leqslant 10.135 \AA, 14.305 \leqslant c \leqslant 14.326 \AA), P 6 /$ mcc. The characteristic chemical substitution is: $\mathrm{Fe}^{3+}+\square \rightleftharpoons \mathrm{Fe}^{2+}+(\mathrm{K}+\mathrm{Na})^{+}$. Six crystal structures have been refined to $0.020 \leqslant$ $R_{\text {obs }} \leqslant 0.026$. They have the osumilite/milarite-type structure, with Si entering the double tetrahedral $T 1$ six-membered rings, and $\mathrm{Mg}$ and Fe entering both the ring-linking $T 2$ tetrahedra, and the $A$ octahedra. The 12-coordinated $C$ site, located between two double rings of $T 1$ tetrahedra, is occupied mainly by $\mathrm{K}$ and subordinately by $\mathrm{Na}$. Furthermore, $\mathrm{Na}$ occupies the partially empty nine-fold coordinated $B$ site which occurs both in the ideal $(z=0)$ and in a split-atom position along the c direction.
\end{abstract}

KEYwORDS: roedderite, chayesite, milarite group, lamproite, Cancarix, Spain.

\section{Introduction}

Chayesite [ $\mathrm{K}\left(\mathrm{Mg}, \mathrm{Fe}^{2+}\right)_{4} \mathrm{Fe}^{3+} \mathrm{Si}_{12} \mathrm{O}_{30}$ ] and roedderite $\left[\mathrm{KNaMg}_{2}\left(\mathrm{Mg}_{3} \mathrm{Si}_{12} \mathrm{O}_{30}\right)\right]$ are linked by the substitution $\mathrm{Fe}^{3+}+\square \rightleftharpoons \mathrm{Fe}^{2+}+(\mathrm{K}+\mathrm{Na})^{+}$ and belong to the osumilite (or milarite) group of minerals (Velde et al., 1989; Fleischer and Mandarino, 1991; Hawthorne et al., 1991) with the crystal chemical formula ${ }^{[6]} A_{2}{ }^{[9]} B_{2}{ }^{[12]} C^{[18]} D^{[4]} T 2{ }^{[4]} T 1_{12} \mathrm{O}_{30}$ (where: ${ }^{[6]} A=$ $\mathrm{Fe}^{2+}, \mathrm{Fe}^{3+}, \mathrm{Li}, \mathrm{Mg}, \mathrm{Mn}^{2+}, \mathrm{Na}, \mathrm{Sn}, \mathrm{Ti}, \mathrm{Zn}, \mathrm{Zr}$; ${ }^{\left[{ }^{[9]}\right.} \mathrm{B}=\mathrm{Na}, \mathrm{H}_{2} \mathrm{O}, \square, \mathrm{Ca}, \mathrm{K}$ ?; ${ }^{[12]} \mathrm{C}=\mathrm{K}, \mathrm{Na}, \mathrm{Ca}$, $\mathrm{Ba} ;{ }^{[18]} \mathrm{D}=\square$, ?; ${ }^{[4]} \mathrm{T2}=\mathrm{Al}, \mathrm{Be}, \mathrm{Fe}^{2+}, \mathrm{Fe}^{3+}, \mathrm{Li}$, $\mathrm{Mg} ;{ }^{[4]} \mathrm{Tl}=\mathrm{Si}, \mathrm{Al}$ ), which crystallize in the $P 6 /$ $m c c, P \overline{6} 2 c$ and, probably, Acam, Aba2 space groups (Armbruster, 1989; Fleischer and Mandarino, 1991). Each $T 1$ tetrahedron shares three corners with adjacent $T 1$ tetrahedra to form six-membered double rings that are linked each other, laterally and vertically, by sharing the fourth corner with an $A$ octahedron and a $T 2$ tetrahedron. $T 2$ tetrahedra and $A$ octahedra form edge-sharing 12 -membered rings. Along the channels, formed by the $T 1$ double rings alternating with the $T 2 / A$ rings, the $C$ and $D$ sites occur in twelve and eighteen coordination, respectively. Sandwiched between two adjacent $A$ octahedra are the $B$ sites in octahedral or nine coordination (Abraham et al., 1983; Armbruster and Oberhänsli, 1988a,b; Khan et al., 1972). In the Bragg classification of the silicates, osumilite-type minerals belong to double-ring structures, and to the tetrahedral framework structures if the chemical identity of tetrahedrally coordinated cations is not considered (Zoltai, 1960; Liebau, 1985). Hawthorne and Smith (1986), in a topological approach to the derivation and characterization of four-connected three-dimensional nets for framework silicate structures, assigned the osumilite-type structures to net 279 which consists of six- ( $T 1$ tetrahedra) and ninemembered ( $T 1$ and $T 2$ tetrahedra) rings, each of which is arranged along the [001] direction to form channels which contain $A$ octahedra, $B, C$, and $D$ sites (Fig. 1). Hawthorne et al. (1991), according to this topological structural model, also discussed the crystal chemistry of the osumilite-type minerals.

Crystal-structure refinement of the Mg-bearing osumilite-type minerals, roedderite, eifelite and

Mineralogical Magazine, December 1994, Vol. 58, pp. 655-662

(C) Copyright the Mineralogical Society 

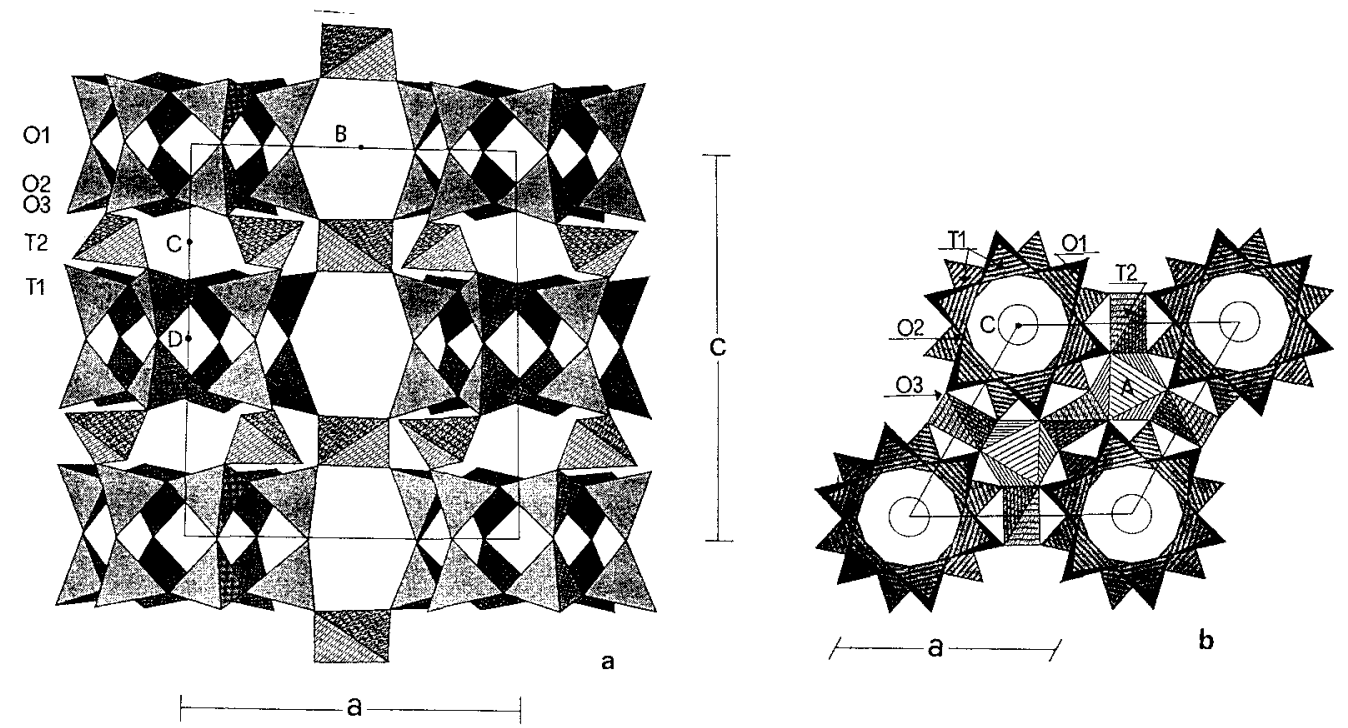

FIG. 1. Polyhedral representation of the osumilite-type structure $(a)$ projected onto $(101)$ and $(b)$ projected onto (001). $A$ polyhedra are omitted in the projection onto (101) for clarity.

merrihueite, shows unusual 4-coordination for $\mathrm{Mg}$, which occupies the $T 2$ site (Abraham et al., 1983; Armbruster, 1989; Khan et al., 1972). Furthermore, in roedderite, the $B$ site splits into two different $B$ positions: $B 1$, preferentially occupied by $\mathrm{Na}$, and $B 2$, which is either empty or contains only small amounts of $\mathrm{Na}$; this reduces the symmetry from $P 6 / m c c$ to $P \overline{6} 2 c$ (Armbruster, 1989). The occurrences and the conditions of crystallization of natural and synthetic minerals of the osumilite group have been summarized by Hawthorne et al. (1991).

The aim of this work is to characterize the crystal-chemical structure of minerals intermediate in composition between roedderite and chayesite $\left(0.42 \leqslant \mathrm{Fe}^{3+} \leqslant 0.87\right.$ apfu; $0.00 \leqslant \mathrm{Fe}^{2+} \leqslant 1.19$ apfu; $0.14 \leqslant \mathrm{Na} \leqslant 0.62 \mathrm{apfu}$ ), and to relate the crystal-chemical results to the evolution of the host melts.

\section{Sample description}

The samples were collected from the lamproitic outcrop at Sierra de las Cabras, c. $0.7 \mathrm{~km}$ from Cancarix (Albacete province, SE Spain). The outcrop consists (Contini et al., 1993) of a main central body of holocrystalline, fine-grained, sanidine-K-richterite (with $\mathrm{Na}-\mathrm{Fe}$-rich arfvedsonite rims)-olivine-phlogopite-diopside (plus late accessory $\mathrm{Na}-\mathrm{Fe}$-clinopyroxene)-rich rocks surrounded by glass-rich lavas.
Roedderite-chayesite (Fig. 2) are accessory minerals in the Cancarix rocks (Wagner and Velde, 1986), associated with Ti-rich (pseudobrookite, rutile) and $\mathrm{K}-\mathrm{Zr}-\mathrm{Ti}$-rich (dalyite) phases; they occur as anhedral grains and are distinctly pleochroic, colourless to deep blue. Usually, they fill voids (sample SP719); sometimes, they are intergrown with amphibole (sample SP724). The crystallization of roedderitechayesite minerals therefore occurred contemporaneously with or subsequently to the crystallization of amphibole (K-richterite and/or arfvedsonite rims) at $c .1000^{\circ} \mathrm{C}$ (S. Mariani, pers. comm.). In the lavas surrounding the main body,

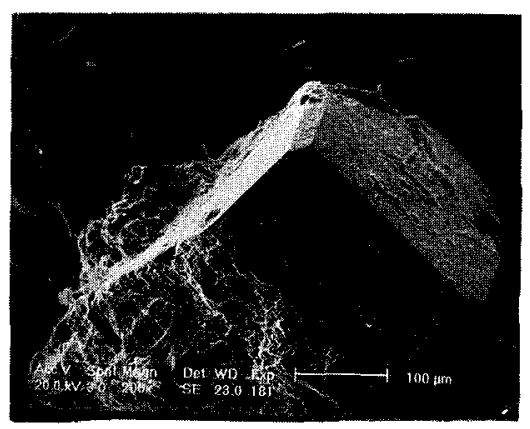

FIG. 2. Scanning electron photomicrograph of a crystal of roedderite-chayesite. 
TABLE 1. Representative electron microprobe analyses and chemical formulae of Cancarix roedderitechayesite

\begin{tabular}{|c|c|c|c|c|c|c|c|c|c|c|c|c|c|c|}
\hline & 1 & 2 & 3 & 4 & 5 & 6 & 7 & 11 & 13 & 16 & 18 & 24 & 27 & 30 \\
\hline \multicolumn{15}{|c|}{ Chemical composition (mean of 10 point analyses) } \\
\hline $\mathrm{SiO}_{2}$ & 70.64 & 70.80 & 70.68 & 71.13 & 71.13 & 70.59 & 70.94 & 71.21 & 71.03 & 69.83 & 69.80 & 70.60 & 68.98 & 68.75 \\
\hline $\mathrm{TiO}_{2}$ & 0.19 & 0.23 & 0.11 & 0.04 & 0.06 & 0.05 & 0.07 & 0.11 & 0.16 & 0.20 & 0.18 & 0.11 & 0.08 & 0.20 \\
\hline $\mathrm{Al}_{2} \mathrm{O}_{3}$ & 0.27 & 0.23 & 0.12 & 0.32 & 0.20 & 0.23 & 0.34 & 0.28 & 0.32 & 0.21 & 0.19 & 0.19 & 0.15 & 0.14 \\
\hline $\mathrm{Fe}_{2} \mathrm{O}_{3}{ }^{*}$ & 6.47 & 4.70 & 5.36 & 6.52 & 5.21 & 5.31 & 5.55 & 5.75 & 4.78 & 4.67 & 3.27 & 4.39 & 6.70 & 5.81 \\
\hline $\mathrm{FeO}^{*}$ & & & & & & & 0.17 & 0.05 & 0.99 & 4.62 & 3.09 & 1.99 & 5.29 & 8.15 \\
\hline $\mathrm{MnO}$ & 0.10 & 0.28 & 0.03 & 0.03 & 0.25 & 0.25 & 0.14 & 0.09 & - & 0.10 & 0.10 & 0.56 & 0.23 & 0.33 \\
\hline $\mathrm{MgO}$ & 16.47 & 17.22 & 17.07 & 16.72 & 17.13 & 16.92 & 16.94 & 16.96 & 16.87 & 14.51 & 16.05 & 16.16 & 12.85 & 11.45 \\
\hline $\mathrm{CaO}$ & 0.02 & - & 0.02 & 0.02 & - & - & 0.03 & 0.02 & - & - & 0.02 & - & - & - \\
\hline $\mathrm{BaO}$ & 0.06 & -. & 0.06 & 0.07 & - & - & 0.03 & - & - & 0.06 & - & - & - & - \\
\hline $\mathrm{Na}_{2} \mathrm{O}$ & 0.62 & 1.68 & 0.92 & 0.90 & 1.83 & 1.90 & 1.26 & 1.13 & 1.41 & 1.34 & 1.78 & 1.39 & 0.43 & 0.69 \\
\hline $\mathrm{K}_{2} \mathrm{O}$ & 4.18 & 4.13 & 4.31 & 3.99 & 3.71 & 3.70 & 4.42 & 4.40 & 4.40 & 4.31 & 4.57 & 4.61 & 4.50 & 4.47 \\
\hline Sum & 99.02 & 99.27 & 98.68 & 99.74 & 99.52 & 98.95 & 99.891 & 100.00 & 99.96 & 99.85 & 99.05 & 100.00 & 99.21 & 99.99 \\
\hline \multicolumn{15}{|c|}{ Structural formulae on the basis of 30 oxygens } \\
\hline $\mathrm{Si}$ & 11.95 & 11.95 & 11.98 & 11.94 & 11.96 & 11.95 & 11.93 & 11.94 & 11.94 & 11.96 & 11.96 & 11.96 & 11.97 & 11.97 \\
\hline $\mathrm{Al}$ & 0.05 & 0.05 & 0.02 & 0.06 & 0.04 & 0.05 & 0.07 & 0.06 & 0.06 & 0.04 & 0.04 & 0.04 & 0.03 & 0.03 \\
\hline Sum & 12.00 & 12.00 & 12.00 & 12.00 & 12.00 & 12.00 & 12.00 & 12.00 & 12.00 & 12.00 & 12.00 & 12.00 & 12.00 & 12.00 \\
\hline $\mathrm{Ti}$ & 0.02 & 0.03 & 0.01 & - & 0.01 & 0.01 & 0.01 & 0.01 & 0.02 & 0.03 & 0.02 & 0.01 & 0.01 & 0.03 \\
\hline $\mathrm{Fe}^{3+}$ & 0.82 & 0.60 & 0.68 & 0.82 & 0.66 & 0.68 & 0.70 & 0.73 & 0.61 & 0.60 & 0.42 & 0.56 & 0.87 & 0.76 \\
\hline $\mathrm{Fe}^{2+}$ & & & & & & & 0.02 & 0.01 & 0.14 & 0.66 & 0.44 & 0.28 & 0.77 & 1.19 \\
\hline Mn & 0.01 & 0.04 & - & - & 0.04 & 0.04 & 0.02 & 0.01 & - & 0.01 & 0.02 & 0.08 & 0.03 & 0.05 \\
\hline $\mathrm{Mg}$ & 4.15 & 4.33 & 4.31 & 4.18 & 4.29 & 4.27 & 4.25 & 4.24 & 4.23 & 3.70 & 4.10 & 4.07 & 3.32 & 2.97 \\
\hline Sum & 5.00 & 5.00 & 5.00 & 5.00 & 5.00 & 5.00 & 5.00 & 5.00 & 5.00 & 5.00 & 5.00 & 5.00 & 5.00 & 5.00 \\
\hline m.a.n. & 71.81 & 69.22 & 69.62 & 71.48 & 69.86 & 70.14 & & & & & & & & \\
\hline $\mathrm{Na}$ & 0.20 & 0.55 & 0.30 & 0.29 & 0.60 & 0.62 & 0.41 & 0.37 & 0.46 & 0.44 & 0.59 & 0.46 & 0.14 & 0.23 \\
\hline K & 0.90 & 0.89 & 0.93 & 0.85 & 0.80 & 0.80 & 0.95 & 0.94 & 0.94 & 0.94 & 1.00 & 1.00 & 1.00 & 0.99 \\
\hline Sum & 1.10 & 1.44 & 1.23 & 1.14 & 1.40 & 1.42 & $1.37 \dagger$ & 1.31 & 1.40 & 1.38 & 1.59 & 1.46 & 1.14 & 1.22 \\
\hline m.a.n. & 19.30 & 22.96 & 20.97 & 19.34 & 21.80 & 22.02 & & & & & & & & \\
\hline \multicolumn{15}{|c|}{ m.a.n. for structural sites based on $\mathrm{X}$-ray refinement } \\
\hline$T 2$ & 42.30 & 44.40 & 43.32 & 44.40 & 44.40 & 45.06 & & & & & & & & \\
\hline$A$ & 29.60 & 24.80 & 26.34 & 27.07 & 25.41 & 25.12 & & & & & & & & \\
\hline$T 2+A$ & 71.90 & 69.20 & 69.66 & 71.47 & 69.81 & 70.18 & & & & & & & & \\
\hline$C$ & 18.19 & 18.11 & 18.41 & 17.73 & 17.37 & 17.37 & & & & & & & & \\
\hline$B$ & 1.13 & 4.90 & 2.46 & 1.47 & 4.36 & 4.62 & & & & & & & & \\
\hline$C+B$ & 19.32 & 23.01 & 20.87 & 19.20 & 21.73 & 21.99 & & & & & & & & \\
\hline
\end{tabular}

Note: ${ }^{*}$ For method of calculation see text; $\uparrow \mathrm{Ca}=0.01$. Analyses $1-6$ refer to the same crystals used in the structure refinement; analyses 7-30 refer to crystals analysed in thin-section; analyses 1-13 refer to crystals in rock sample SP719; analyses 16-30 to crystals in rock sample SP724. m.a.n. = mean atomic number.

roedderite and chayesite are very rare and occur as anhedral-subhedral crystals which are colourless to weakly pleochroic (light blue tint, uniaxial positive) filling cavities and vugs.

\section{Experimental}

The average chemical compositions (ARL-SEMQ electron microprobe analysis of polished thinsections and of crystals used for structure refinement, Table 1) are representative of each entire crystal. $\mathrm{H}_{2} \mathrm{O}$ was determined on selected crystals by thermal analysis (DTA, TG, DTG) using a SEIKO SSC/5200 apparatus (temperature rate: $10^{\circ} / \mathrm{min}$ in the range $T_{\mathrm{amb}}-1000^{\circ} \mathrm{C}$ under argon flow).

Crystals examined preliminarily by precession photographs have hexagonal symmetry with $h h l$, $h \bar{h} l, h 0 l$ present only with $l=2 n$. The crystals with the highest iron content $\left(\mathrm{Fe}^{3+}>0.82 \mathrm{apfu}\right)$ 
TABLE 2. Lattice constants and some crystallographic data of roedderite-chayesite crystals studied

\begin{tabular}{llllllllllll}
\hline Sample & dimensions (mm) & s.m.,w. & $N_{\text {obs }}$ & $R_{\text {sym }}$ & $R_{\text {all }}$ & $R_{\text {obs }}$ & h.m.r. & $a[\AA]^{*}$ & $c[\AA]^{*}$ & $\mathrm{Vol}_{\text {. }\left[\AA^{3}\right]^{*}}$ \\
\hline 1 & $0.12 \times 0.15 \times 0.15$ & $\omega, 1.50$ & 538 & 0.022 & 0.029 & 0.026 & 0.57 & $10.118(1)$ & $14.300(3)$ & 1267.8 \\
2 & $0.21 \times 0.22 \times 0.22$ & $\omega, 1.20$ & 694 & 0.013 & 0.028 & 0.026 & 0.33 & $10.124(1)$ & $14.305(1)$ & 1269.8 \\
3 & $0.17 \times 0.22 \times 0.24$ & $\omega, 1.20$ & 612 & 0.018 & 0.026 & 0.025 & 0.35 & $10.122(2)$ & $14.320(2)$ & 1270.6 \\
4 & $0.12 \times 0.17 \times 0.17$ & $\omega, 1.00$ & 657 & 0.017 & 0.023 & 0.021 & 0.32 & $10.128(1)$ & $14.312(1)$ & 1271.4 \\
5 & $0.12 \times 0.12 \times 0.14$ & $\omega, 0.80$ & 596 & 0.016 & 0.023 & 0.021 & 0.37 & $10.135(1)$ & $14.320(1)$ & 1273.9 \\
6 & $0.11 \times 0.12 \times 0.21$ & $\omega, 0.90$ & 658 & 0.015 & 0.021 & 0.020 & 0.36 & $10.126(1)$ & $14.326(1)$ & 1272.1 \\
\hline
\end{tabular}

Note: Esd's on the last significant digit are in parentheses; s.m.,w: scan mode, width [ $\left.{ }^{\circ}\right]$

$R_{\text {sym }}=\Sigma_{h k l} \Sigma_{i=1}^{N}\left|\mathbf{I}_{h k l_{i}}-\mathbf{I}_{h k l}\right| / \Sigma_{h k l} \Sigma_{i=1}^{N} \mathbf{I}_{h k l} ;$

h.m.r.: highest map residual $\left(\mathrm{e}^{-} / \AA^{3}\right)$;

determined on 25 reflections $\left(25^{\circ} \leqslant 2 \theta \leqslant 50^{\circ}\right)$.

are unsuitable for structural investigation. Intensity data $\left(4^{\circ} \leqslant 2 \theta \leqslant 66^{\circ}\right)$ were collected with an ENRAF-NONIUS CAD4 automated four-circle diffractometer operating at $52 \mathrm{kV}$ and $40 \mathrm{~mA}$ with graphite-monochromated Mo- $K \alpha \mathrm{X}$ ray radiation. Unit cell dimensions and additional information on X-ray data measurement and structure refinement are reported in Table 2 . Absorption corrections were applied according to the semi-empirical method of North et al. (1968). Data were corrected for Lorentz-polarization and background effects then averaged and reduced to structure factors. The refined coordinates for osumilite (Armbruster and Oberhänsli, 1988a) were used as input to the least-squares program of the system SHELX-76 (Sheldrick, 1976). Subsequent difference-Fourier maps indicated residual density at $1 / 3,2 / 3,0$ assigned to the $B$ site. Upon conversion to an anisotropic displacement model, the displacement model of the $B$ site showed unreasonably large anisotropy in three crystals $(2,5,6)$. This was taken as evidence for positional disorder of the $B$-cation. The electron density was modelled as a split site with an isotropic displacement factor. Crystal-structure refinement does not indicate ordering into $B$ sites in $P \overline{6} 2 c$, and we prefer the space group $P 6 / m c c$. We used scattering factors for ionized $\mathrm{Fe}, \mathrm{Mg}, \mathrm{K}$ and $\mathrm{Na}$, and mixed scattering factors (in the ratio 1:1) for tetrahedral $T 1$ and anion sites. Cycles of least-squares refinement with anisotropic displacement parameters, variable occupancy of $\mathrm{K} v s$. Na and $\mathrm{Fe} v s . \mathrm{Mg}$, converged to the final positional and anisotropic parameters listed in Table 3. Table 4 lists the selected bond-lengths, angles and distortion parameters. A supplementary Table of observed and calculated structure factors is available from the editor on request.

\section{Crystal chemistry}

The samples studied are unzoned, but the compositions of crystals from the same rock sample are variable (Table 1 ). The main chemical variations involve the $\mathrm{Fe}_{\text {tot }} / \mathrm{Mg}$ ratio (0.138 to 0.656 ), which is highest in the chayesite intergrown with amphibole (sample SP724), and the $\mathrm{Na} / \mathrm{K}$ ratio ( 0.140 to 0.775$)$, and compositions plot close to the solid-solution line $\mathrm{Fe}^{3+}+\square \rightleftharpoons \mathrm{Fe}^{2+}+$ $(\mathrm{K}+\mathrm{Na})^{+}$(Fig. 3) that links the two ideal endmembers.

$T 1$ tetrahedron. The $\langle T 1-\mathrm{O}\rangle$ bond-lengths $(1.609 \leqslant<T 1-\mathrm{O}\rangle \leqslant 1.611 \AA)$ suggest constant occupancy of the $T 1$ site. In particular, microprobe chemical analyses (samples 1-6) have an average Si content of 11.96 apfu, close to the number (12) of $T 1$ sites corresponding to the structural formula. Hawthorne et al. (1991) found a predictive relationship between tetrahedral $\langle T 1-\mathrm{O}\rangle$ bond-lengths and $\mathrm{Al}$ content [i.e. $\langle T 1-\mathrm{O}\rangle=1.609+1.0_{\left(\mathrm{r}_{T}\right)}$, where $\mathrm{r}_{T 1}$ is the mean radius of the $T 1$ cations]. Our samples conform to the linear relationship and plot close to milarite, which represents the Si-rich end-member (Fig. 4).

T2 tetrahedron. The $T 2$ tetrahedron is large $(1.934 \leqslant T 2-\mathrm{O} \leqslant 1.941 \AA)$ and extremely distorted indicating that $\mathrm{Mg}$ occupies the $T 2$ site. The $T 2-\mathrm{O}$ bond-length is a little shorter (eifelite: $T 2-\mathrm{O}=1.989 \AA$; merrihueite: $T 2-\mathrm{O}=1.955 \AA$ ) and the scattering is slightly higher than would be expected if the site was occupied only by $\mathrm{Mg}$; thus we conclude that some $\mathrm{Fe}^{3+}$ also occurs at the $T 2$ site. $T 2-\mathrm{O}$ bond-length could be also affected by the size of the $A$ octahedron and by the $B$ position and occupancy (Hawthorne et al., 1991). In samples which show the $B$ site at $z=0$, the 
TABLE 3. Atom coordinates and displacement factors $\left[\AA^{2}\right]$ for roedderite-chayesite crystals

\begin{tabular}{|c|c|c|c|c|c|c|c|c|c|c|}
\hline Atom & $x / a$ & $y / b$ & $z / c$ & $B_{\mathrm{eq}}$ & $\beta_{11}^{*}$ & $\beta_{22}^{*}$ & $\beta_{33}^{*}$ & $\beta_{12}^{*}$ & $\beta_{13}^{*}$ & $\beta_{23}^{*}$ \\
\hline \multicolumn{11}{|c|}{ Sample 1} \\
\hline 01 & $0.1298(3)$ & $0.3948(3)$ & 0 & $1.76(9)$ & $2.3(1)$ & $2.1(1)$ & $1.01(9)$ & $1.1(1)$ & 0 & 0 \\
\hline $\mathrm{O} 2$ & $0.2195(2)$ & $0.2776(2)$ & $0.1332(1)$ & $1.58(7)$ & $1.54(7)$ & $1.87(7)$ & $1.63(7)$ & $1.07(6)$ & $0.01(6)$ & $-0.06(6)$ \\
\hline O3 & $0.1545(2)$ & $0.4964(2)$ & $0.1725(1)$ & $1.25(6)$ & $1.19(6)$ & $1.32(6)$ & $1.22(6)$ & $0.61(5)$ & $-0.10(6)$ & $-0.18(6)$ \\
\hline$T 1$ & $0.23840(7)$ & $0.35292(7)$ & $0.39072(4)$ & $0.92(2)$ & $0.94(2)$ & $1.06(2)$ & $0.84(2)$ & $0.56(2)$ & $0.05(2)$ & $0.05(2)$ \\
\hline$T 2$ & $1 / 2$ & $1 / 2$ & $1 / 4$ & $0.86(5)$ & $0.60(4)$ & $1.52(9)$ & $0.77(5)$ & $0.76(4)$ & 0 & 0 \\
\hline$A$ & $1 / 3$ & $2 / 3$ & $1 / 4$ & $1.82(4)$ & $1.73(4)$ & $1.73(4)$ & $2.00(8)$ & $0.87(2)$ & 0 & 0 \\
\hline$C$ & 0 & 0 & $1 / 4$ & $2.04(5)$ & $2.02(5)$ & $2.02(5)$ & $2.1(\mathrm{I})$ & $1.01(3)$ & 0 & 0 \\
\hline$B$ & $1 / 3$ & $2 / 3$ & 0 & $1.2(5)$ & - & - & - & - & - & - \\
\hline \multicolumn{11}{|c|}{ Sample 2} \\
\hline 01 & $0.1299(2)$ & $0.3945(2)$ & 0 & $1.91(6)$ & $2.35(8)$ & $1.93(7)$ & $1.37(7)$ & $1.02(7)$ & 0 & 0 \\
\hline $\mathrm{O} 2$ & $0.2193(1)$ & $0.2776(1)$ & $0.13327(9)$ & $1.73(5)$ & $1.67(5)$ & $1.96(5)$ & $1.95(5)$ & $1.21(4)$ & $0.04(4)$ & $0.02(4)$ \\
\hline $\mathrm{O} 3$ & $0.1550(1)$ & $0.4966(1)$ & $0.17245(8)$ & $1.34(4)$ & $1.23(4)$ & $1.34(4)$ & $1.45(4)$ & $0.64(3)$ & $-0.08(4)$ & $-0.19(4)$ \\
\hline$T l$ & $0.23814(5)$ & $0.35274(5)$ & $0.39066(3)$ & $0.99(1)$ & $0.94(2)$ & $1.02(2)$ & $1.09(2)$ & $0.53(1)$ & $0.04(1)$ & $0.06(1)$ \\
\hline$T 2$ & $1 / 2$ & $1 / 2$ & $1 / 4$ & $1.10(3)$ & $0.78(3)$ & $1.72(6)$ & $1.12(3)$ & $0.86(3)$ & 0 & 0 \\
\hline$A$ & $1 / 3$ & $2 / 3$ & $1 / 4$ & $1.03(3)$ & $0.95(3)$ & $0.95(3)$ & $1.18(6)$ & $0.48(2)$ & 0 & 0 \\
\hline$C$ & 0 & 0 & $1 / 4$ & $2.10(4)$ & $1.98(4)$ & $1.98(4)$ & $2.34(7)$ & $0.99(2)$ & 0 & 0 \\
\hline$B$ & $1 / 3$ & $2 / 3$ & $-0.0202(7)$ & $1.7(2)$ & - & - & - & - & - & - \\
\hline \multicolumn{11}{|c|}{ Sample 3} \\
\hline 01 & $0.1297(2)$ & $0.3938(2)$ & 0 & $1.85(7)$ & $2.21(9)$ & $2.12(9)$ & $1.25(7)$ & $1.10(8)$ & 0 & 0 \\
\hline $\mathrm{O} 2$ & $0.2194(2)$ & $0.2777(2)$ & $0.1334(1)$ & $1.74(5)$ & $1.68(5)$ & $2.04(6)$ & $1.94(6)$ & $1.27(5)$ & $0.00(5)$ & $0.03(5)$ \\
\hline O3 & $0.1549(1)$ & $0.4965(2)$ & $0.17246(9)$ & $1.38(5)$ & $1.22(5)$ & $1.34(5)$ & $1.57(5)$ & $0.64(4)$ & $-0.09(4)$ & $-0.17(5)$ \\
\hline$T 1$ & $0.23828(5)$ & $0.35296(5)$ & $0.39076(4)$ & $1.07(2)$ & $0.95(2)$ & $1.07(2)$ & $1.25(2)$ & $0.55(1)$ & $0.03(2)$ & $0.06(2)$ \\
\hline$T 2$ & $1 / 2$ & $1 / 2$ & $1 / 4$ & $1.09(4)$ & $0.70(3)$ & $1.67(7)$ & $1.22(4)$ & $0.84(3)$ & 0 & 0 \\
\hline$A$ & $1 / 3$ & $2 / 3$ & $1 / 4$ & $1.26(4)$ & $1.26(3)$ & $1.22(3)$ & $1.63(6)$ & $0.84(3)$ & 0 & 0 \\
\hline$C$ & 0 & 0 & $1 / 4$ & $1.84(5)$ & $1.62(5)$ & $1.62(5)$ & $2.27(9)$ & $0.81(2)$ & 0 & 0 \\
\hline$B$ & $1 / 3$ & $2 / 3$ & 0 & $2.0(3)$ & - & - & - & - & - & - \\
\hline \multicolumn{11}{|c|}{ Sample 4} \\
\hline $\mathrm{OI}$ & $0.1304(2)$ & $0.3947(2)$ & 0 & $1.63(6)$ & $1.95(8)$ & $1.55(7)$ & $1.39(7)$ & $0.87(6)$ & 0 & 0 \\
\hline $\mathrm{O} 2$ & $0.2198(1)$ & $0.2781(1)$ & 0.133 & $1.49(4)$ & $1.36(5)$ & $1.68(5)$ & $1.82(5)$ & $1.05(4)$ & $0(4)$ & $-0.01(4)$ \\
\hline O3 & $0.1553(1)$ & $0.4971(1)$ & $0.17254(8)$ & $1.07(4)$ & $0.90(4)$ & $0.95(4)$ & $1.33(4)$ & $0.45(3)$ & $-0.12(3)$ & $-0.24(4)$ \\
\hline$T 1$ & $0.23803(5)$ & $0.35318(4)$ & $0.39069(3)$ & $0.78(1)$ & $0.66(1)$ & $0.75(1)$ & $0.99(2)$ & $0.40(1)$ & $0.06(1)$ & $0.08(1)$ \\
\hline 72 & $1 / 2$ & $1 / 2$ & $1 / 4$ & $0.89(3)$ & $0.53(3)$ & $1.44(6)$ & $1.00(3)$ & $0.72(3)$ & 0 & 0 \\
\hline$A$ & $1 / 3$ & $2 / 3$ & $1 / 4$ & $0.89(2)$ & $0.71(2)$ & $0.71(2)$ & $1.24(5)$ & $0.36(1)$ & 0 & 0 \\
\hline$C$ & 0 & 0 & $1 / 4$ & 1.76 & $1.60(3)$ & $1.60(3)$ & $2.07(6)$ & $0.80(2)$ & 0 & 0 \\
\hline$B$ & $1 / 3$ & $2 / 3$ & 0 & $0.8(4)$ & - & . & - & - & - & - \\
\hline \multicolumn{11}{|c|}{ Sample 5} \\
\hline $\mathrm{Ol}$ & 0.1299 & $0.3943(2)$ & 0. & $1.66(7)$ & $2.25(9)$ & $1.81(8)$ & $0.90(7)$ & $1.00(8)$ & 0 & 0 \\
\hline $\mathrm{O} 2$ & $0.2197(2)$ & $0.2777(2)$ & $0.13325(9)$ & $1.50(5)$ & $1.56(5)$ & $1.77(5)$ & $1.56(5)$ & $1.11(5)$ & $0.04(5)$ & $0.05(5)$ \\
\hline O3 & $0.1552(1)$ & $0.4967(1)$ & $0.17230(8)$ & $1.10(4)$ & $1.04(5)$ & $1.13(4)$ & $1.10(4)$ & $0.53(4)$ & $-0.08(4)$ & $-0.18(4)$ \\
\hline$T 1$ & $0.23807(5)$ & $0.35288(5)$ & $0.39065(3)$ & $0.80(2)$ & $0.84(2)$ & $0.92(2)$ & $0.72(2)$ & $0.49(1)$ & $0.05(2)$ & $0.07(2)$ \\
\hline$T 2$ & $1 / 2$ & $1 / 2$ & $1 / 4$ & $0.83(3)$ & $0.59(3)$ & $1.56(7)$ & $0.66(3)$ & $0.78(3)$ & 0 & 0 \\
\hline$A$ & $1 / 3$ & $2 / 3$ & $1 / 4$ & $0.84(3)$ & $0.80(3)$ & $0.80(3)$ & $0.93(5)$ & $0.40(2)$ & 0 & 0 \\
\hline$C$ & 0 & 0 & $1 / 4$ & $1.64(4)$ & $1.55(4)$ & $1.55(4)$ & $1.80(7)$ & $0.78(2)$ & 0 & 0 \\
\hline$B$ & $1 / 3$ & $2 / 3$ & $-0.0188(8)$ & $1.0(2)$ & - & - & - & - & - & - \\
\hline \multicolumn{11}{|c|}{ Sample 6} \\
\hline $\mathrm{Ol}$ & $0.1299(2)$ & $0.3943(2)$ & 0 & $1.61(5)$ & $2.14(8)$ & $1.73(7)$ & 0.95 & $0.96(6)$ & 0 & 0 \\
\hline $\mathrm{O} 2$ & $0.2197(1)$ & $0.2778(1)$ & $0.13331(8)$ & $1.46(4)$ & $1.44(5)$ & $1.74(5)$ & $1.62(4)$ & $1.10(4)$ & $-0.01(4)$ & $0.02(4)$ \\
\hline O3 & $0.1551(1)$ & $0.4967(1)$ & $0.17248(7)$ & $1.07(4)$ & $1.04(4)$ & $1.07(4)$ & $1.09(4)$ & $0.53(3)$ & $-0.10(3)$ & $-0.23(4)$ \\
\hline$T 1$ & $0.23814(4)$ & $0.35284(4)$ & $0.39067(3)$ & $0.77(1)$ & $0.79(1)$ & $0.87(1)$ & $0.72(1)$ & $0.46(1)$ & $0.05(1)$ & $0.07(1)$ \\
\hline$T 2$ & $1 / 2$ & $1 / 2$ & $1 / 4$ & $0.85(3)$ & $0.59(3)$ & $1.57(6)$ & $0.72(3)$ & $0.78(3)$ & 0 & 0 \\
\hline$A$ & $1 / 3$ & $2 / 3$ & $1 / 4$ & $0.76(3)$ & $0.71(3)$ & $0.71(3)$ & $0.85(5)$ & $0.36(2)$ & 0 & 0 \\
\hline$C$ & 0 & 0 & $1 / 4$ & $1.61(3)$ & $1.54(3)$ & $1.54(3)$ & $1.76(6)$ & $0.77(2)$ & 0 & 0 \\
\hline$B$ & $1 / 3$ & $2 / 3$ & $-0.0190(7)$ & $1.5(2)$ & - & - & - & - & - & - \\
\hline
\end{tabular}

Note: Esd's on the last significant digit are in parentheses;

the form of the anisotropic thermal parameter is: $\exp \left[-1 / 4\left(B_{11} h^{2} a^{* 2}+B_{22} k^{2} b^{* 2}+B_{33} l^{2} c^{* 2}+2 B_{12} h k a^{*} b^{*}+2 B_{13} h^{*} a^{*} c^{*}+\right.\right.$ $\left.\left.2 \mathrm{~B}_{23} \mathrm{klb}^{*} \mathrm{c}^{*}\right)\right]$. 


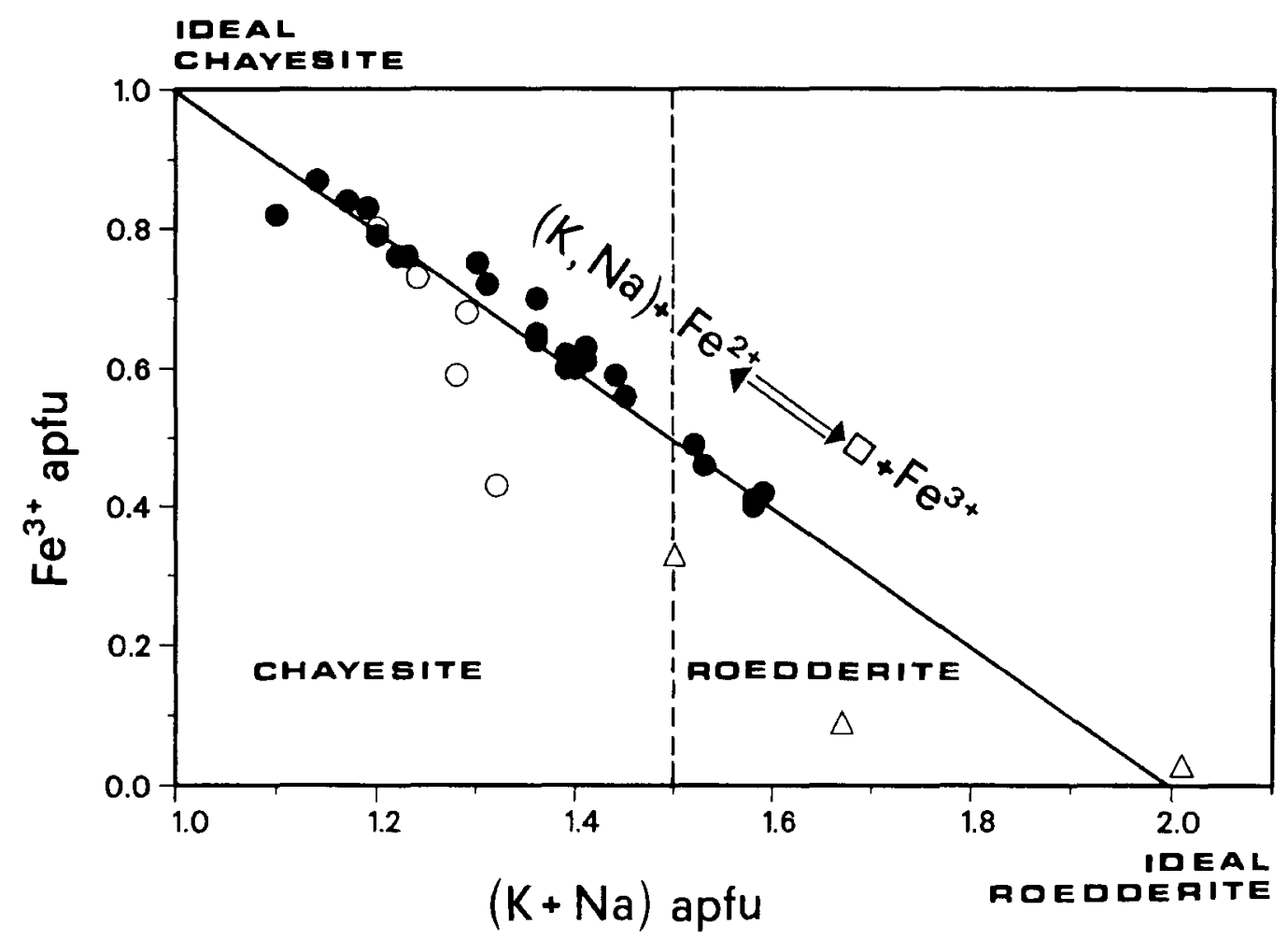

Fig. 3. Plot of calculated $\mathrm{Fe}^{3+}$ content (apfu) vs. $(\mathrm{Na}+\mathrm{K})$ content (apfu). Filled circles: samples from this study; open circles: chayesites from Moon Canyon (Velde et al., 1989); triangles: Bellerberg roedderites (Abraham et al., 1983). The points reported in the plot refer to all analysed crystals. Ideal roedderite: $\mathrm{KNaMg}_{5} \mathrm{Si}_{12} \mathrm{O}_{30}$; ideal chayesite: $\mathrm{K}\left(\mathrm{Mg}, \mathrm{Fe}^{2+}\right)_{4} \mathrm{Fe}^{3+} \mathrm{Si}_{12} \mathrm{O}_{30}$.

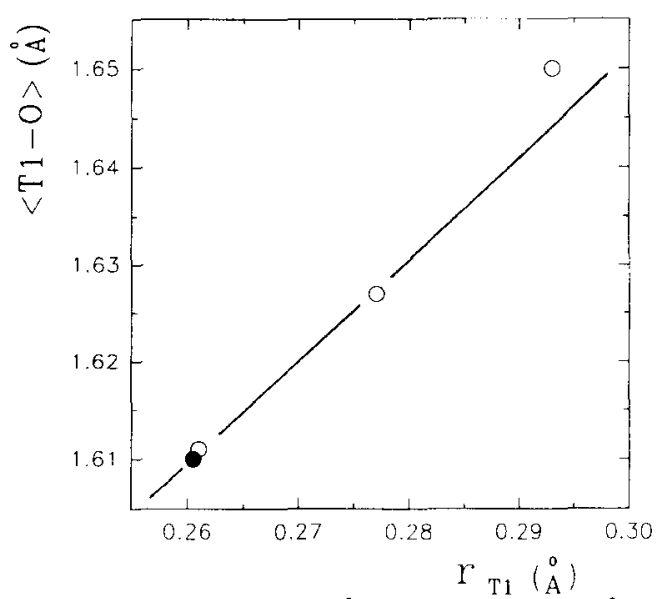

FIG. 4. Plot of $\langle T 1-\mathrm{O}\rangle[\AA]$ s. cation radius $[\AA]$ at the $T 1$ site. The filled circle is the mean data of the studied samples; the open circles are the mean values of the data for milarite, osumilite and armenite reported by Hawthorne et al. (1991) as well as the straight line. observed small increase in $T 2 \mathrm{O} v s . T 2$ occupancy can be attributed to the presence of large cations (e.g. $\mathrm{Fe}^{2+}, \mathrm{Mn}^{2+}$ ) as well (Tables 1 and 4).

$A, B$, and $C$ polyhedra. Site-occupancy refinement indicates small amounts of iron in the $A$ octahedron; the $A-\mathrm{O}$ bond-lengths, indicate this iron to be in the trivalent state. The population of the $C$ site consists of $\mathrm{K}$ with small amounts of $\mathrm{Na}$ $(0.10 \leqslant \mathrm{Na} \leqslant 0.20 \mathrm{apfu})$. The incorporation of alkaline cations $(\mathrm{Na})$ in the ideally empty $B$ (or $B^{\prime}$ ) polyhedron is the charge compensation mechanism for the incorporation of $\mathrm{Mg}$ at $T 2$ in excess of the ideal amount $\mathrm{Fe}^{3+}: \mathrm{Mg}^{2+}=1: 2$.

In all samples, difference-Fourier maps show maxima $\left(2.0 \leqslant \mathrm{e}^{-} / \AA^{3} \leqslant 4.0\right.$ ) close to $1 / 3,2 / 3,0$ (site symmetry 6). Therefore, samples 2,5 and 6 , with $\mathrm{Na}$ at $1 / 3,2 / 3,0$, had a large displacement parameter along the $c$ axis, suggesting that $\mathrm{Na}$ is disordered at positions of the type $1 / 3,2 / 3, z$ (site symmetry 3 , with $-0.020 \leqslant z \leqslant-0.018$ ), with $\mathrm{Na}$ showing distorted ninefold coordination. The refined scattering at the $B$ site is in good agreement with 
TABLE 4. Selected bond-lenghts and angles from structure refinement of roedderite-chayesite crystals

\begin{tabular}{|c|c|c|c|c|c|c|}
\hline & 1 & 2 & 3 & 4 & 5 & 6 \\
\hline$C-\mathrm{O} 2[\times 12]$ & $3.062(1)$ & $3.062(1)$ & $3.062(1)$ & $3.066(1)$ & $3.067(1)$ & $3.066(1)$ \\
\hline $\begin{array}{l}B-\mathrm{O} 1\left[\begin{array}{ll}\times & 3\end{array}\right] \\
B-\mathrm{O} 3\left[\begin{array}{ll}\times & 6\end{array}\right]([\times 3]) \\
B-\mathrm{O} 3 \\
<B-\mathrm{O}>\end{array}$ & $\begin{array}{l}2.478(2) \\
3.034(2) \\
- \\
2.849\end{array}$ & $\begin{array}{l}2.498(2) \\
3.273(9) \\
2.803(8) \\
2.858\end{array}$ & $\begin{array}{l}2.487(2) \\
3.036(1) \\
- \\
2.853\end{array}$ & $\begin{array}{l}2.480(1) \\
3.033(1) \\
-\quad \\
2.849\end{array}$ & $\begin{array}{l}2.501(2) \\
3.257(9) \\
2.819(9) \\
2.859\end{array}$ & $\begin{array}{l}2.499(2) \\
3.262(9) \\
2.819(8) \\
2.860\end{array}$ \\
\hline$A-\mathrm{O} 3[\times 6]$ & $2.087(1)$ & $2.085(1)$ & $2.086(1)$ & $2.079(1)$ & $2.087(1)$ & $2.085(1)$ \\
\hline $\begin{array}{l}\mathrm{O} 3-\mathrm{O} 3\left[\begin{array}{ll}\times & 3\end{array}\right] \\
\mathrm{O} 3-\mathrm{O} 3[\times 3] \\
\mathrm{O} 3-\mathrm{O} 3\left[\begin{array}{ll}\times & 6\end{array}\right] \\
\langle\mathrm{O}-\mathrm{O}\rangle\end{array}$ & $\begin{array}{l}2.917(3) \\
2.757(3) \\
3.062(2) \\
2.950\end{array}$ & $\begin{array}{l}2.914(3) \\
2.758(3) \\
3.057(2) \\
2.947\end{array}$ & $\begin{array}{l}2.916(3) \\
2.760(3) \\
3.058(2) \\
2.948\end{array}$ & $\begin{array}{l}2.912(3) \\
2.753(2) \\
3.051(2) \\
2.942\end{array}$ & $\begin{array}{l}2.918(3) \\
2.765(3) \\
3.058(2) \\
2.950\end{array}$ & $\begin{array}{l}2.916(2) \\
2.760(2) \\
3.057(2) \\
2.948\end{array}$ \\
\hline $\begin{array}{l}T 2-\mathrm{O} 3\left[\begin{array}{ll}\times & 4\end{array}\right] \\
\text { O3-O3 }\left[\begin{array}{ll}\times & 2\end{array}\right] \\
\text { O3-O3 }\left[\begin{array}{ll}\times & 2\end{array}\right] \\
\text { O3-O3 }\left[\begin{array}{ll}\times & 2\end{array}\right] \\
\langle\mathrm{O}-\mathrm{O}>\end{array}$ & $\begin{array}{l}1.932(2) \\
3.500(3) \\
2.757(3) \\
3.164(4) \\
3.140\end{array}$ & $\begin{array}{l}1.936(1) \\
3.509(2) \\
2.758(3) \\
3.173(3) \\
3.147\end{array}$ & $\begin{array}{l}1.936(2) \\
3.509(3) \\
2.760(3) \\
3.172(3) \\
3.147\end{array}$ & $\begin{array}{l}1.937(1) \\
3.513(2) \\
2.753(2) \\
3.177(3) \\
3.148\end{array}$ & $\begin{array}{l}1.941(2) \\
3.518(2) \\
2.765(3) \\
3.181(3) \\
3.155\end{array}$ & $\begin{array}{l}1.937(1) \\
3.511(2) \\
2.760(2) \\
3.175(3) \\
3.149\end{array}$ \\
\hline $\begin{array}{l}\mathrm{O} 3-T 2-\mathrm{O} 3\left[\begin{array}{ll}\times & 2\end{array}\right] \\
\mathrm{O} 3-T 2-\mathrm{O} 3\left[\begin{array}{ll}\times & 2\end{array}\right] \\
\mathrm{O} 3-T 2-\mathrm{O} 3\left[\begin{array}{ll}\times & 2\end{array}\right] \\
\langle\mathrm{O}-T 2-\mathrm{O}> \\
\mathrm{TAV}_{T 2}\end{array}$ & $\begin{array}{l}129.9(1) \\
91.02(8) \\
109.9(1) \\
110.27 \\
303.2\end{array}$ & $\begin{array}{r}129.97(7) \\
90.82(6) \\
110.08(7) \\
110.29 \\
307.4\end{array}$ & $\begin{array}{l}129.93(9) \\
90.91(7) \\
110.01(8) \\
110.28 \\
305.4\end{array}$ & $\begin{array}{l}130.16(7) \\
90.59(6) \\
110.17(7) \\
110.31 \\
314.0\end{array}$ & $\begin{array}{r}129.99(8) \\
90.83(6) \\
110.05(8) \\
110.29 \\
307.6\end{array}$ & $\begin{array}{l}129.99(7) \\
90.84(5) \\
110.04(7) \\
110.29 \\
307.4\end{array}$ \\
\hline $\begin{array}{l}T 1-\mathrm{O} 1 \\
T 1-\mathrm{O} 2 \\
T 1-\mathrm{O} 2 \\
T 1-\mathrm{O} 3 \\
<T 1-\mathrm{O}>\end{array}$ & $\begin{array}{l}1.606(1) \\
1.622(2) \\
1.624(2) \\
1.582(2) \\
1.609\end{array}$ & $\begin{array}{l}1.607(1) \\
1.621(1) \\
1.625(1) \\
1.584(1) \\
1.609\end{array}$ & $\begin{array}{l}1.606(1) \\
1.623(2) \\
1.626(2) \\
1.583(2) \\
1.610\end{array}$ & $\begin{array}{l}1.607(1) \\
1.621(2) \\
1.630(2) \\
1.586(1) \\
1.611\end{array}$ & $\begin{array}{l}1.609(1) \\
1.624(2) \\
1.626(2) \\
1.583(1) \\
1.611\end{array}$ & $\begin{array}{l}1.609(1) \\
1.623(2) \\
1.624(2) \\
1.585(1) \\
1.610\end{array}$ \\
\hline $\begin{array}{l}\mathrm{O} 1-\mathrm{O} 2 \\
\mathrm{O} 1-\mathrm{O} 2 \\
\mathrm{O} 1-\mathrm{O} 3 \\
\mathrm{O} 2-\mathrm{O} 2 \\
\mathrm{O} 2-\mathrm{O} 3 \\
\mathrm{O} 2-\mathrm{O} 3 \\
<\mathrm{O}-\mathrm{O}>\end{array}$ & $\begin{array}{l}2.649(2) \\
2.633(3) \\
2.635(2) \\
2.566(1) \\
2.601(2) \\
2.665(3) \\
2.625\end{array}$ & $\begin{array}{l}2.652(2) \\
2.632(2) \\
2.637(1) \\
2.567(1) \\
2.607(2) \\
2.665(2) \\
2.627\end{array}$ & $\begin{array}{l}2.651(2) \\
2.631(3) \\
2.642(2) \\
2.567(1) \\
2.604(2) \\
2.663(3) \\
2.626\end{array}$ & $\begin{array}{l}2.656(2) \\
2.634(2) \\
2.641(1) \\
2.572(1) \\
2.608(2) \\
2.666(2) \\
2.630\end{array}$ & $\begin{array}{l}2.652(2) \\
2.632(3) \\
2.639(1) \\
2.572(1) \\
2.607(2) \\
2.667(2) \\
2.628\end{array}$ & $\begin{array}{l}2.652(2) \\
2.634(2) \\
2.642(1) \\
2.570(1) \\
2.605(2) \\
2.665(2) \\
2.628\end{array}$ \\
\hline $\begin{array}{l}\mathrm{O} 1-T 1-\mathrm{O} 2 \\
\mathrm{O} 2-T 1-\mathrm{O} 1 \\
\mathrm{O} 1-T 1-\mathrm{O} 3 \\
\mathrm{O} 2-T 1-\mathrm{O} 2 \\
\mathrm{O} 2-T 1-\mathrm{O} 3 \\
\mathrm{O} 3-T 1-\mathrm{O} 2 \\
<\mathrm{O}-T 1-\mathrm{O}> \\
\mathrm{TAV}_{T 1}\end{array}$ & $\begin{array}{l}110.2(1) \\
109.2(1) \\
111.5(1) \\
104.5(1) \\
108.58(8) \\
112.5(1) \\
109.41 \\
\quad 7.97\end{array}$ & $\begin{array}{c}110.23(7) \\
109.2(1) \\
111.46(8) \\
104.53(8) \\
108.66(6) \\
112.49(7) \\
109.43 \\
7.76\end{array}$ & $\begin{array}{l}110.21(9) \\
109.2(1) \\
111.9(1) \\
104.41(8) \\
108.50(7) \\
112.36(8) \\
109.43 \\
8.38\end{array}$ & $\begin{array}{c}110.26(7) \\
109.3(1) \\
111.59(8) \\
104.61(7) \\
108.39(6) \\
112.44(7) \\
109.43 \\
7.81\end{array}$ & $\begin{array}{c}110.12(8) \\
109.2(1) \\
111.54(9) \\
104.62(8) \\
108.66(7) \\
112.51(8) \\
109.44 \\
7.64\end{array}$ & $\begin{array}{c}110.19(7) \\
109.18(8) \\
111.66(8) \\
104.6(7) \\
108.52(6) \\
112.41(7) \\
109.43 \\
7.73\end{array}$ \\
\hline
\end{tabular}

Note: Esd's on the last significant digit are in parentheses;

TAV as in Robinson et al. (1971).

the excess $\mathrm{Na}$ given by chemical analysis. It is worth noting that the samples analysed are anhydrous, which excludes any effect of water on the displacement of the $B$ site along the $c$ axis, as is the case in milarite (Hawthorne et al., 1991).

\section{Concluding remarks}

Minerals of the chayesite-roedderite series from Cancarix lamproites have variable chemistry characterized by the substitution $\mathrm{Fe}^{3+}+\square \rightleftharpoons$ $\mathrm{Fe}^{2+}+(\mathrm{K}+\mathrm{Na})^{+}$, trending from chayesite to roedderite with progressive crystallization. Crystallization of olivine and (subordinately) clinopyroxene, phlogopite and sanidine led to the progressive increase in $\mathrm{Fe} / \mathrm{Mg}$ and $\mathrm{Na} / \mathrm{K}$ of the solidifying melts. In particular, the $\mathrm{Na} / \mathrm{K}$ ratio reached its peak with the separation of the arfvedsonitic rims, and then decreased from the early- to the later-crystallized grains of chayesitelike phases ( $\mathrm{Na} / \mathrm{K}$ ratios 0.6 and 0.1 , respectively). Thus, the crystallization of the roedderite-type minerals, with $\mathrm{Na} / \mathrm{K}$ substitution at the $C$ site and/ or very low Na occupancy at the $B$ site, record the 
inversion in the activity of $\mathrm{Na}$ and $\mathrm{K}$ in the residual magmatic fractions, from which crystallize K-rich phases such as dalyite, end-products of the Cancarix magma fractionation.

The increase in $\mathrm{Fe}^{3+}$ at the $T 2$ tetrahedron with continued crystallization supports the notion of an increase in the activity of oxygen in the very late stages of crystallization, as suggested by the crystallization of $\mathrm{Fe}^{3+}$-bearing pseudobrookite (Brigatti et al., 1993) and by the increase in $\mathrm{Fe}^{3+}$ in the late clinopyroxene and amphibole (Contini et al., 1993). The increase in oxygen fugacity was accompanied by low $P_{\mathrm{H}_{2} \mathrm{O}}$, as suggested by the absence of $\mathrm{H}_{2} \mathrm{O}$ in the studied minerals.

\section{Acknowledgements}

Financial support was provided by the Ministero della Università e Ricerca Scientifica (MURST) and Consiglio Nazionale delle Ricerche (CNR) d'Italia. CNR is also acknowledged for the use of the ARL-SEMQ electron microprobe at the Istituto di Mineralogia e Petrografia of Modena University.

\section{References}

Abraham, K., Gebert, W., Medenbach, O., Schreyer, W. and Hentschel, G. (1983) Eifelite, $\mathrm{KNa}_{3} \mathrm{Mg}_{4} \mathrm{Si}_{12} \mathrm{O}_{30}$, a new mineral of the osumilite group with octahedral sodium. Contrib. Mineral. Petrol., 82, 252-8.

Armbruster, T. (1989) Crystal chemistry of doublering silicates: structure of roedderite at $100^{\circ}$ and $300^{\circ}$ K. Eur. J. Mineral., 1, 715-8.

Armbruster, T. and Oberhänsli, R. (1988a) Crystal chemistry of double-ring silicates: structural, chemical and optical variation in osumilites. Amer. Mineral., 73, 585-94.

Armbruster, T. and Oberhänsli, R. (1988b) Crystal chemistry of double-ring silicates: structure of sugilite and brannockite. Amer. Mineral., 73, 595-600.

Brigatti, M.F., Contini, S., Capedri, S. and Poppi, L. (1993) Crystal chemistry and cation ordering in Pseudobrookite and armalcolite from Spanish lamproites. Eur. J. Mineral., 5, 73-94.

Contini, S., Venturelli, G., Toscani, L., Capedri, S. and Barbieri, M. (1993) Cr-Zr-armalcolite-bearing lamproites of Cancarix, SE Spain. Mineral. Mag., 57, 203-16.

Fleischer, M. and Mandarino, J.A. (1991) Glossary of mineral species. Mineralogical Record, Tucson.

Hawthorne, F.C. and Smith, J.V. (1986) Enumeration of 4-connected 3-dimensional nets and classification of framework silicates. 3D nets based on insertion of 2-connected vertices into 3connected plane nets. Zeit. Krist., 175, 15-30.

Hawthorne, F.C., Mitsuyoshi, K., Černý, P., Ball, N., Rossman, G. R. and Grice, J.D. (1991) The crystal chemistry of the milarite-group minerals. Amer. Mineral., 76, 1836-56.

Khan, A.A., Baur, W.H. and Forbes, W.C. (1972) Synthetic magnesian merrihueite, dipotassium penta-magnesium dodecasilicate: tetrahedral magnesiosilicate framework crystal structure. Acta Cryst., B28, 267-72.

Liebau, F. (1985) Structural chemistry of silicates. Springer-Verlag, Berlin

North, A.C.T., Phillips, D.C. and Mathews, F.S. (1968) A semi-empirical method of absorption correction. Acta Cryst., A24, 351-9.

Robinson, K., Gibbs, G.V. and Ribbe, P.H. (1971) Quadratic elongation: A quantitative measure of distortion in coordination polyhedra. Science, 172, 567-70.

Sheldrick, G.M. (1976) SHELX-76. Programme for crystal structure determination. Univ. Cambridge, England.

Velde, D., Medenbach, O., Wagner, C. and Schreyer, W. (1989) Chayesite, $\mathrm{K}\left(\mathrm{Mg}, \mathrm{Fe}^{+2}\right)_{4} \mathrm{Fe}^{3+} \mathrm{Si}_{12} \mathrm{O}_{30}$ : a new rock forming silicate mineral of the osumilite group from the Moon Canyon (Utah) lamproite. Amer. Mineral., 74, 1368-73.

Wagner, C. and Velde, D. (1986) The mineralogy of K-bearing lamproites. Amer. Mineral., 71, 17-37.

Zoltai, T. (1960) Classification of silicates and other minerals with tetrahedral structures. Amer. Mineral, 45, 960-73.

[Manuscript received 15 February 1994: revised 12 April 1994] 